\title{
Goldenhar Syndrome Presenting As Squamosal Chronic Otitis Media
}

\author{
Ravi Ambewadi ${ }^{1} \quad$ Vikram Kemmannu Bhat $^{1}$ Prajna Laxman Salian ${ }^{1}$ \\ ${ }^{1}$ Department of Otolaryngology, Head and Neck Surgery, Karnataka \\ Institute of Medical Sciences, Hubli, Karnataka, India \\ Address for correspondence Vikram Kemmannu Bhat, MS, DNB, \\ MNAMS, PhD, Department of Otolaryngology, Head and Neck \\ Surgery, Karnataka Institute of Medical Sciences, Vidyanagar, \\ Hubli 580021, Karnataka, India (e-mail: vikram.ent@gmail.com).
}
Abstract
Keywords
- hearing loss
- otitis media
- Goldenhar syndrome

Goldenhar syndrome is a rare congenital anomaly involving the eye, ear, vertebra, and the mandible. This anomaly presenting primarily to the ENT outpatient clinic with ear discharge and cholesteatoma is still rarer. Here we describe one such rare case that was a challenge to diagnose as well as manage. We also discuss the various problems in the management and highlight the need for a multispecialty approach to tackling the various pathologies in such a case.

\section{Introduction}

Goldenhar syndrome (GHS) also known as oculo-auriculo-vertebral syndrome is a rare congenital anomaly characterized by the involvement of first and second branchial arches, manifesting as microtia, periauricular appendices, epibulbar dermoid, hypoplasia of zygomatic, mandibular and maxillary bones, facial muscle hypoplasia, and vertebral abnormalities.

\section{Case Report}

An 18-year-old female born to nonconsanguineous parents, presented with right ear discharge and decreased hearing since childhood. She was the third child and her two other siblings did not have similar complaints.

On examination she had right ear microtia and post auricular skin tags ( - Fig. 1A). External auditory canal (EAC) was found to be stenosed and filled with discharge. On the left side, preauricular skin tag was present (-Fig. 1B). Right lower motor neuron partial facial paralysis involved the forehead, angle of mouth but spared the eye. Asymmetry of the craniofacial skeleton and hemifacial microsomia on right side was obvious. On ophthalmic examination, bulbar conjunctival limbal dermoid in the right eye and bulbar conjunctival dermoid in the left eye were detected ( - Fig. 2 ). Consultation references were also given to orthopaedics, maxillofacial surgery, plastic surgery, and internal medicine for examination. However, abnormalities like vertebral deformities, cleft lip, or palate did not exist. Hence it was decided on consensus to operate on the mastoid first and perform the other surgeries later.

Ear swab culture detected Pseudomonas species. Pure tone audiometry of the right ear revealed severe to profound mixed hearing loss. High resolution computed tomography (CT) of the temporal bone revealed atresia of EAC, sclerosed mastoid and cholesteatoma in the right middle ear, erosions of the bony ossicular chain, asymmetry of internal auditory meati, and hypoplasia of right condyle of mandible ( Fig. 3A, B).

She was started on intravenous antibiotics as per the ear swab report. She was then posted for right mastoidectomy and reconstruction. Pars tensa showed central perforation with granulation tissue. Attic too was filled with granulation tissue and was drilled out. Malleus, part of incus, footplate of stapes with single crus were present. Facial canal, however, seemed to be normal. Mastoid cortex was sclerosed and contracted ( - Fig. 4A, B). Canal wall down mastoidectomy was done. Attic reconstruction was done with cartilage harvested from post aural appendage. Meatoplasty was done with a T-shaped incision on conchal cartilage and redundant post auricular appendages were excised.

Later, cartilage ossiculoplasty was performed and temporalis fascia graft was placed in the middle ear to cover both attic cartilage as well as the reconstructed ossicular chain. Canaloplasty was performed to widen the stenotic bony 


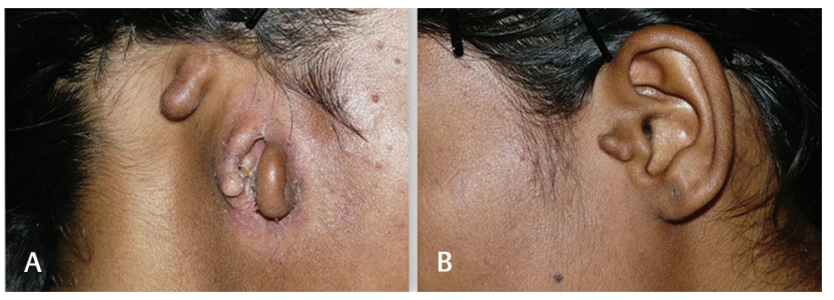

Fig. 1 (A) Picture showing the anomalies in the right external ear, (B) left external ear.

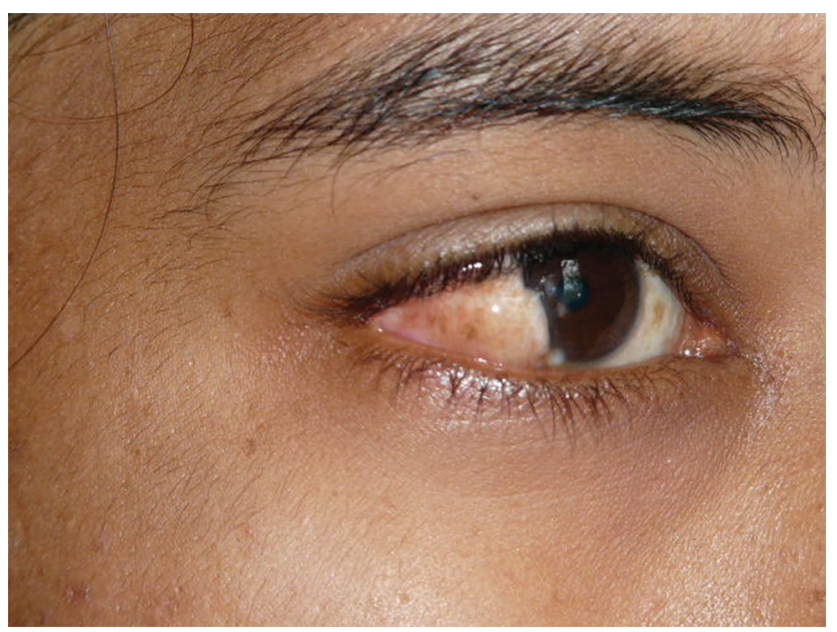

Fig. 2 Picture showing the involvement of the right eye. external ear canal and split skin grafts (from margins of incision) were placed on the bare areas. A snugly fitting soft silastic tube stent was placed in the EAC. A povidone iodine tulle drain was kept from the mastoid cavity to the ear canal through the meatoplasty. This was removed after 1 week. There were no intraoperative or postoperative complications. After the mastoid surgery, the patient was advised to visit the department of plastic surgery for the reconstruction of the pinna. The stent was removed after 6 months during follow-up. No recurrence of disease was observed during a follow-up of 1 year.

\section{Discussion}

GHS affects multiple organs of the body simultaneously. Frequently there is asymmetry of face and cosmetic correction of the defects is quite elaborate and time consuming. Hence correction of these anomalies itself is quite challenging and adds to the expenditure and morbidity of the patient. At times there are odd findings that are not a part of the classical picture. Dhingra et al $^{1}$ found nasal polyposis in their case.

This patient presented first time to the hospital with the classical picture of GHS with complaints of ear discharge and hearing impairment. Accessory tragus is a consistent feature of GHS. ${ }^{2}$ Microtia is the most frequent finding in
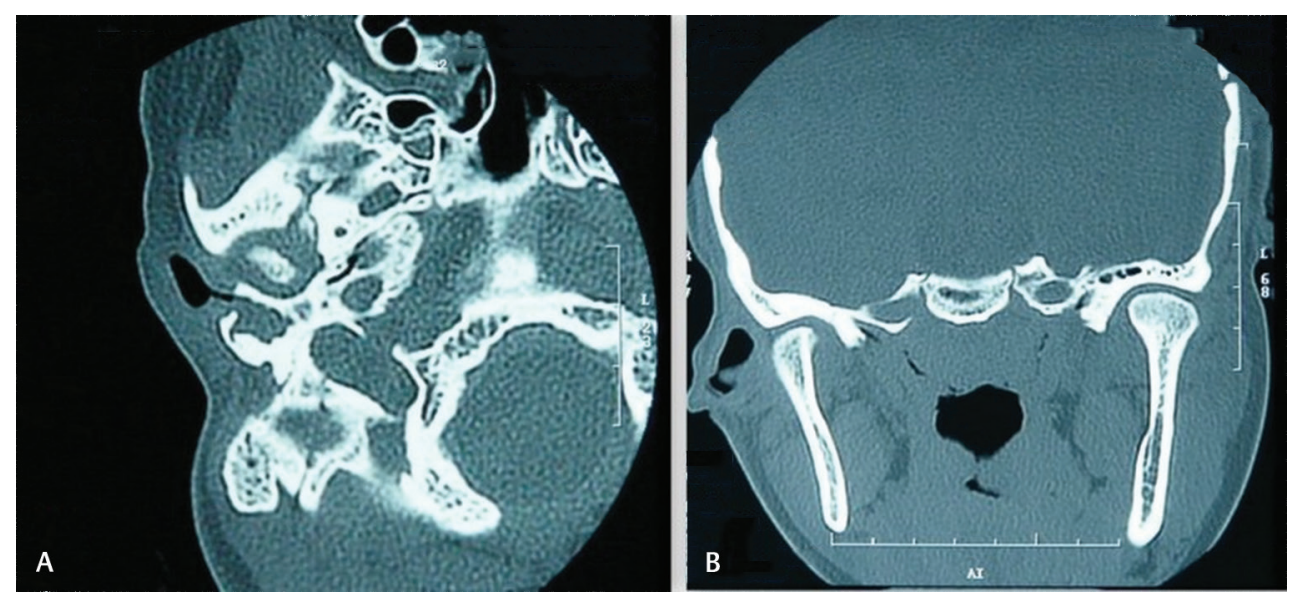

Fig. 3 (A) CT scan axial section showing right external anomalies, (B) coronal section showing hypoplasia of right mandible. CT, computed tomography.

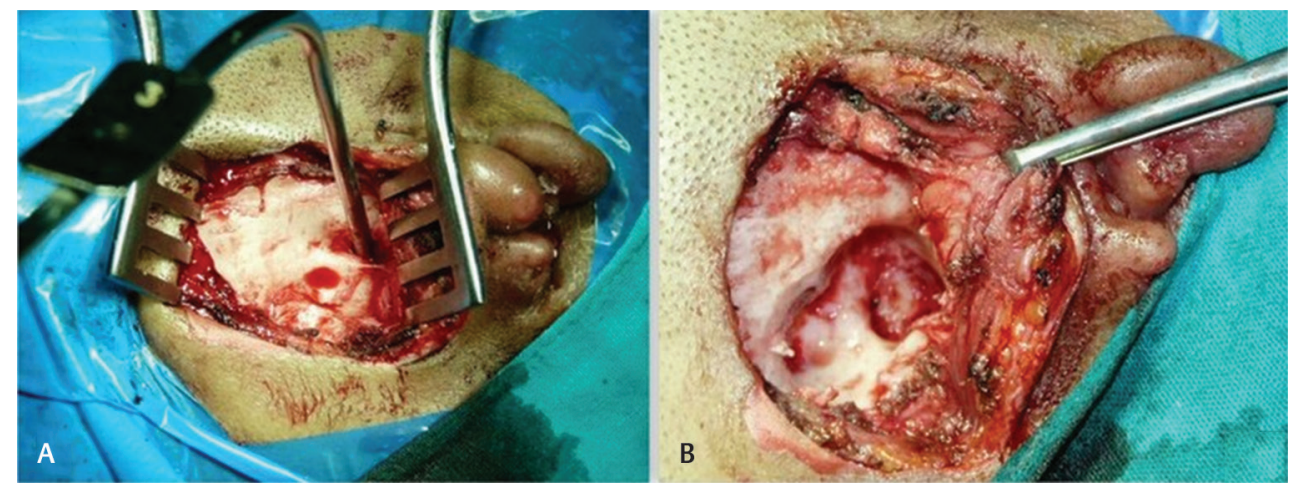

Fig. 4 (A) Operative photograph showing dehiscence in bony mastoid (instrument inserted), (B) canal wall down mastoidectomy in progress. 
GHS. ${ }^{3}$ The degree of hearing loss deteriorated as the grade of microtia increased. ${ }^{4}$ Both these findings were observed in this patient. However, ours was not a full-blown case of the syndrome, probably because of which the patient had not reported earlier. Even though several cases of cholesteatoma in the ear are reported in literature ( - Table $\mathbf{1}$ ), none of the middle ear cholesteatoma cases presented with chronic ear discharge. To the best of our knowledge, this is the first such case to be reported. The lack of ear discharge may partly be due to the agenesis of the external ear canal. This may also be the reason behind the pathogenesis of external ear cholesteatoma that may arise due to the improper scavenging of the epithelium in the ear canal. Besides the maldevelopment of the Eustachian tube and mastoid are responsible for the improper aeration of the middle ear that probably contributes to the development of retraction pockets and cholesteatoma. However, middle ear cholesteatoma reported so far in literature (-Table $\mathbf{1}$ ) is less common than external ear cholesteatoma. Complications of cholesteatoma in GHS are rare and only mastoid abscess with fistula has been reported. ${ }^{5}$ The agenesis of various structures in the external and middle ear makes the disease clearance and the reconstruction very difficult. The chances of recurrences are also high due to the abnormal anatomy, not to mention the cosmetic outlook after the surgery. One of the ways to tackle the irregularly shaped mastoid cavity is by obliteration of the same, even though unreported in literature.

The most frequent neurological manifestation was facial nerve paralysis. ${ }^{6}$ The actual cause of facial palsy in our case was unclear as, there was no dehiscence or compression of the nerve observed in the high-resolution CT scan or during the mastoid surgery. Also, it was unlikely that the cholesteatoma was the cause of the facial palsy. Some of the cases reported in literature had facial palsy even in the absence of cholesteatoma. ${ }^{7,8}$ Hypoplasia of the nerve is the probable cause as reported in few cases before. ${ }^{7}$ This makes the condition difficult to treat. The absence of a proper external ear canal necessitates the need for a bony canaloplasty and also placement of a silastic stent in the canal to prevent the collapse and restenosis. Barkdull and Carvalho ${ }^{9}$ have used orogastric tube as stent to dilate the reconstructed EAC. Pinna reconstruction would need to be taken up in the second sitting.

Table 1 Cases with cholesteatoma or ear involvement reported across the world in the past 20 years

\begin{tabular}{|c|c|c|c|c|c|c|c|c|}
\hline Authors & Year & Place & $\begin{array}{l}\text { Total } \\
\text { cases }\end{array}$ & $\begin{array}{l}\text { External ear } \\
\text { findings }\end{array}$ & $\begin{array}{l}\text { Middle ear } \\
\text { findings }\end{array}$ & Inner ear findings & $\begin{array}{l}\text { Hearing } \\
\text { loss }\end{array}$ & $\begin{array}{l}\text { Facial } \\
\text { nerve } \\
\text { palsy }\end{array}$ \\
\hline $\begin{array}{l}\text { Dhingra } \\
\text { et al }^{1}\end{array}$ & 2020 & India & 1 & $\begin{array}{l}\text { Low set ears } \\
\text { Preauricular } \\
\text { tag }(R), \\
\text { Microtia (R), } \\
\text { Agenesis of } \\
\text { EAC (R) }\end{array}$ & $\begin{array}{l}\text { Agenesis of middle ear } \\
\text { cavity and ossicles (R) }\end{array}$ & & $\begin{array}{l}\text { Severe } \\
\text { MHL }\end{array}$ & $\begin{array}{l}\text { Yes } \\
\text { (L) }\end{array}$ \\
\hline Hodge et $\mathrm{al}^{5}$ & 2019 & $\begin{array}{l}\text { United } \\
\text { States }\end{array}$ & 3 & $\begin{array}{l}\text { EAC chole- } \\
\text { steatoma (3), } \\
\text { Microtia (3) }\end{array}$ & Not involved & & & No \\
\hline $\begin{array}{l}\text { Hennersdorf } \\
\text { et al }{ }^{10}\end{array}$ & 2014 & Germany & 21 & $\begin{array}{l}\text { Atresia/stenosis } \\
\text { of EAC (19) }\end{array}$ & $\begin{array}{l}\text { Ossicular chain } \\
\text { dysplasia (19), } \\
\text { Absent ossicles (1), } \\
\text { Opaque/Narrowed } \\
\text { middle ear (14), } \\
\text { Opaque antrum (12) }\end{array}$ & $\begin{array}{l}\text { Aberrant petrous } \\
\text { segment of } \\
\text { ICA (1), IAC } \\
\text { malformation (5), } \\
\text { Cochlear } \\
\text { anomaly (2), } \\
\text { SCC changes (5) }\end{array}$ & $\begin{array}{l}\text { Isolated } \\
\text { severe } \\
\mathrm{CHL}(4 / 7) \\
\mathrm{MHL}(3 / 7)\end{array}$ & No \\
\hline Rosa et $\mathrm{al}^{3}$ & 2011 & Brazil & 12 & Microtia (12) & $\begin{array}{l}\text { Middle ear opacity (2) } \\
\text { Displaced middle ear (2) } \\
\text { Malformed ossicles (2) } \\
\text { Nonaerated mastoid (5) }\end{array}$ & Agenesis (2) & $\begin{array}{l}\text { CHL, } \\
\text { SNHL } \\
\text { (Some) }\end{array}$ & No \\
\hline Jin et $\mathrm{al}^{4}$ & 2010 & China & 208 & $\begin{array}{l}\text { Microtia } \\
\text { Preauricular } \\
\text { sinus/tags } \\
(14.4 \%), \\
\text { EAC stenosis } \\
(98.6 \%)\end{array}$ & Cholesteatoma (15) & & $\begin{array}{l}\mathrm{MHL} \\
(55 / 103) \\
\mathrm{CHL} \\
(51 / 103)\end{array}$ & $\begin{array}{l}\text { Yes } \\
(4)\end{array}$ \\
\hline $\begin{array}{l}\text { Barkdull and } \\
\text { Carvalho }^{9}\end{array}$ & 2007 & $\begin{array}{l}\text { United } \\
\text { States }\end{array}$ & 1 & $\begin{array}{l}\text { Microtia (L), } \\
\text { EAC steno- } \\
\text { sis (L), EAC } \\
\text { cholesteatoma }\end{array}$ & Hypoplastic (R) & & & $\begin{array}{l}\text { Yes } \\
(\mathrm{L})\end{array}$ \\
\hline
\end{tabular}


Table 1 (Continued)

\begin{tabular}{|c|c|c|c|c|c|c|c|c|}
\hline Authors & Year & Place & $\begin{array}{l}\text { Total } \\
\text { cases }\end{array}$ & $\begin{array}{l}\text { External ear } \\
\text { findings }\end{array}$ & $\begin{array}{l}\text { Middle ear } \\
\text { findings }\end{array}$ & Inner ear findings & $\begin{array}{l}\text { Hearing } \\
\text { loss }\end{array}$ & $\begin{array}{l}\text { Facial } \\
\text { nerve } \\
\text { palsy }\end{array}$ \\
\hline $\begin{array}{l}\text { Ottaviano } \\
\text { et } \text { al }^{11}\end{array}$ & 2006 & Italy & 1 & $\begin{array}{l}\text { Dysmorphic } \\
\text { pinna }(R), \\
\text { EAC atresia }(R)\end{array}$ & $\begin{array}{l}\text { Dysmorphism of petrous } \\
\text { and mastoid, Absent } \\
\text { stapes }(R), \\
\text { No FC }(R)\end{array}$ & $\begin{array}{l}\text { Absence of inner } \\
\text { ear and } \\
8 \text { th nerve and } \\
\text { IAC }\end{array}$ & & No \\
\hline Reddy et al ${ }^{12}$ & 2005 & India & 1 & $\begin{array}{l}\text { Bilateral } \\
\text { microtia, } \\
\text { Accessory } \\
\text { auricle }(\mathrm{L}) \text {, } \\
\text { EAC stenosis (R) }\end{array}$ & $\begin{array}{l}\text { Sclerosis of middle ear } \\
\text { bilaterally, } \\
\text { Cholesteatoma (R) }\end{array}$ & $\begin{array}{l}\text { Sclerosis of inner } \\
\text { ear bilaterally, } \\
\text { Hypoplastic IAC (L) }\end{array}$ & $\begin{array}{l}\text { Bilateral } \\
\text { SNHL }\end{array}$ & No \\
\hline Rahbar et al ${ }^{7}$ & 2001 & $\begin{array}{l}\text { United } \\
\text { States }\end{array}$ & 40 & $\begin{array}{l}\text { Auricular abnor- } \\
\text { malities (38), } \\
\text { Bilateral } \\
\text { anomalies (7) }\end{array}$ & $\begin{array}{l}\text { Hypoplasia/atresia (36), } \\
\text { Ossicles } \\
\text { malformation (30) }\end{array}$ & $\begin{array}{l}\text { Hypoplasia of oval } \\
\text { window (12) }\end{array}$ & $\begin{array}{l}\mathrm{CHL}(35) \\
\text { SNHL (4) }\end{array}$ & Yes (20) \\
\hline $\begin{array}{l}\text { Lemmerling } \\
\text { et } \mathrm{al}^{8}\end{array}$ & 2000 & Belgium & 1 & $\begin{array}{l}\text { Microtia }(R) \text {, } \\
\text { Preauricular } \\
\text { tag }(R) \text {, } \\
\text { Narrow EAC (R) }\end{array}$ & $\begin{array}{l}\text { Opaque middle ear and } \\
\text { mastoid }(L) \text {, } \\
\text { Malrotation of ossicular } \\
\text { chain with fixation to wall } \\
\text { of middle ear }(R) \\
\text { Absent stapes }(R)\end{array}$ & $\begin{array}{l}\text { Enlarged vestibular } \\
\text { aqueduct (R), } \\
\text { Cochlear dysplasia, } \\
\text { No SCC and FC (R) }\end{array}$ & & $\begin{array}{l}\text { Yes } \\
(R)\end{array}$ \\
\hline
\end{tabular}

Abbreviations: CHL, conductive hearing loss; EAC, external auditory canal; FC, Fallopian canal; IAC, internal auditory canal; ICA, internal carotid artery; L, left; MHL, mixed hearing loss; R, right; SCC, semicircular canal; SNHL, sensory neural hearing loss.

Note: Inside brackets are the actual numbers affected.

\section{Conclusion}

GHS presenting as squamosal chronic otitis media is rare and is challenging to manage because of the development of acquired disease in the backdrop of multiple congenital anomalies. A high index of suspicion is required to identify and diagnose this syndrome when the patient presents with complaints of ear discharge only. Multiorgan involvement affects the quality of life of the patient and is yet another challenge in this syndrome that would determine the number of surgeries to be performed. Correction of these anomalies requires multimodality staged procedures.

\section{Conflict of Interest}

None declared.

\section{Acknowledgments}

The authors would like to thank the Departments of Microbiology, Radiology, Ophthalmology, Orthopaedics, Maxillofacial Surgery, Plastic Surgery, and Internal Medicine, Karnataka Institute of Medical Sciences, Hubli, India for their opinions, kind co-operation, and assistance in getting the investigations done specially for this case.

\section{References}

1 Dhingra P, Souza CD, Parsram K. Nasal polyposis with dextrocardia, pulmonary agenesis and microtia: Goldenhar syndrome - a case report. Int J Otorhinolaryngol Head Neck Surg 2020;6(3):581-584

2 Jansen T, Romiti R, Altmeyer P. Accessory tragus: report of two cases and review of the literature. Pediatr Dermatol 2000;17(5):391-394
3 Rosa RFM, Silva AP, Goetze TB, et al. Ear abnormalities in patients with oculo-auriculo-vertebral spectrum (Goldenhar syndrome) Rev Bras Otorrinolaringol (Engl Ed) 2011;77(4):455-460

4 Jin L, Hao S, Fu Y, Zhang T, Wang Z. Clinical analysis based on 208 patients with microtia (especially reviewed oculo-auriculo-vertebral spectrum, hearing test, CT scan) Turk J Pediatr 2010;52(6):582-587

5 Hodge SE, Peterson AA, O'Connell BP, Drake AF. Clinical presentation of congenital cholesteatoma of the external auditory canal in Goldenhar syndrome: a case series. Int J Otorhinolaryngol 2019;5(2):44-47

6 Touliatou V, Fryssira H, Mavrou A, Kanavakis E, Kitsiou-Tzeli S. Clinical manifestations in 17 Greek patients with Goldenhar syndrome. Genet Couns 2006;17(3):359-370

7 Rahbar R, Robson CD, Mulliken JB, et al. Craniofacial, temporal bone, and audiologic abnormalities in the spectrum of hemifacial microsomia. Arch Otolaryngol Head Neck Surg 2001;127(3):265-271

8 Lemmerling MM, Vanzieleghem BD, Mortier GR, Dhooge IJ, Kunnen MF.Unilateral semicircular canal aplasia in Goldenhar's syndrome. AJNR Am J Neuroradiol 2000;21(7):1334-1336

9 Barkdull GC, Carvalho D. Goldenhar syndrome with external auditory canal stenosis complicated by canal cholesteatoma and first branchial cleft cyst. Int J Pediatr Otorhinolaryngol Extra 2007;2(2):128-132

10 Hennersdorf F, Friese $N$, Löwenheim $H$, Tropitzsch $A$ Ernemann U, Bisdas S. Temporal bone changes in patients with Goldenhar syndrome with special emphasis on inner ear abnormalities. Otol Neurotol 2014;35(5):826-830

11 Ottaviano G, Calzolari F, Martini A. Goldenhar syndrome in association with agenesia of the internal carotid artery. Int J Pediatr Otorhinolaryngol 2007;71(3):509-512

12 Reddy MVV, Reddy PP, Rani PU, Bindu LH. Facio-auricular vertebral syndrome-a case report. Int J Hum Genet 2005;11(3): 156-158 